\title{
A ordem e a desordem da natureza: 0 sertão e a Amazônia em Gastão Cruls
}

\section{Marco Aurélio Coelho Paiva*}

\section{Resumo}

O artigo busca analisar o início da carreira literária de Gastão Cruls e identificar, a partir das suas primeiras publicações, inclusive de seu primeiro romance, os conflitos de ordem profissional a interferir na sua produção literária. Em paralelo com tais inquietações e angústias, então responsáveis por certa cisão do autor entre a medicina e a literatura, também são considerados na análise o modo como a temática dos sertões articulou-se em contraposição à figuração de uma nova realidade urbana surgida no Brasil nos anos 1920. A convergência de tais fatores de ordem subjetiva e objetiva parecem ganhar na obra do autor uma resolução inicial pela via de uma literatura fantástica então emergente.

Palavras-chave: intelectuais. literatura fantástica. Amazônia.

* Universidade Federal do Amazonas, Manaus, AM, Brasil 


\section{The order and disorder of nature: the sertão and the Amazon in Gastão Cruls}

\section{Abstract}

The aim of this article is to analyze the beginning of the literary career of Gastão Cruls and thus identify the themes and styles of his first short stories and novels, all closely linked to his personal drama about pursuing a medical career or dedicating himself to literature. This existential conflict was very important for the author to discover in fantastic literature a way to express not only his personal dramas, but also to analyze the Brazilian society of the 1920s from a new perspective, an urban society in its first steps.

Keywords: intellectuals. fantastic literature. Amazonia.

\section{Introdução}

obra do médico e escritor Gastão Cruls pode ser caracterizada,
em linhas gerais, como uma literatura ainda impregnada por um
tipo de compreensão da realidade brasileira segundo os termos estabelecidos entre os anos finais do século XIX e início do século XX. Uma literatura tributária, portanto, das teorias raciais e dos fatores mesológicos como elementos determinantes para a definição do caráter dos povos e nações (Ortiz, 1994; Schwarcz, 2011). No entanto, para além de tais parâmetros, também é uma obra que se constitui como uma reflexão a distanciar-se da estética naturalista já desgastada e desacreditada nos anos 1920. Os contos e romances do início da carreira literária de Gastão Cruls refletem distintos aspectos presentes tanto naquela realidade sertaneja retratada por uma literatura regionalista de finais do século XIX quanto no ritmo de vida nos centros urbanos em expansão. A consideração de temas e problemas próprios a uma realidade urbana, até então marginalmente explorados pelo realismo/naturalismo (Candido, 1998), redundou em 
uma aposta na literatura de mistério, a abarcar questões e dramas de caráter psicológico ou, ainda, em uma narrativa a enveredar pela ficção científica, ambas se convertendo em tópicos específicos de uma literatura fantástica que começou a arregimentar um número maior de leitores no Brasil, no decênio de 1920 (Silva, 2008). A formação médica de Gastão Cruls, dessa forma, não é um dado menor em relação tanto a seus dramas pessoais relativos a uma carreira literária incerta, quanto às soluções por ele encaminhadas em suas obras, na medida em que sua concepção de medicina destoava das práticas vigentes ${ }^{1}$. Ao dedicar-se ao estudos e práticas da psiquiatria e psicanálise, Cruls rechaçou em seus contos e romances as teses que apregoavam a suposta inferioridade racial da população mestiça em formação no Brasil. Os vilões e personagens problemáticos de suas tramas ou são médicos ou são de origem estrangeira.

Se ao longo das décadas de 1920 e 1930 Gastão Cruls escreveu variados contos voltados para a temática sertaneja, com destaque para a paisagem e a natureza dos sertões do Nordeste (Cruls, 1922; 1923), também é possível identificar, no decorrer desse período, um grupo considerável de narrativas a se debruçar sobre temas e problemáticas atinentes a certos setores médios urbanos então emergentes (Cruls, 1928; 1934; 1949). Mas essa dualidade sertão/meio urbano fez surgir, inicialmente, certo entrave do ponto de vista da formulação de uma linguagem a ser manejada. Os riscos implicados no uso de uma linguagem não adequada poderiam inviabilizar uma associação entre temáticas tão díspares: uma, própria ao meio urbano, a espelhar os dramas de uma determinada camada social aburguesada e, de alguma forma, já identificada a partir dos trabalhos, por exemplo, de Machado de Assis. Outra a ressaltar aspectos da natureza dos sertões longínquos com sua população esquecida, caudatária do estilo de Euclides da Cunha. A opção pela literatura de mistério, desse modo, a despeito dos possíveis vínculos existentes entre a vida urbana e a literatura fantástica

${ }^{1}$ Sobre a institucionalização e práticas da medicina no Brasil, ver Schwarcz (2011). Sobre a carreira médica e dos estudos sobre psiquiatria e psicanálise de Gastão Cruls, ver Vívolo (2017). 
(Todorov, 2010), parece ter surgido como uma saída a conciliar referenciais opostos para a criação literária do autor. Se, do ponto de vista da temática sertaneja, prepondera nos escritos de Gastão Cruls um modo de figuração e descrição da paisagem ainda tributário de certa tradição literária², vale destacar a novidade que uma literatura de cunho fantástico pôde então associar àquela abordagem já consolidada dos sertões - os assuntos próprios e peculiares aos centros urbanos. Os primeiros contos e romances de Gastão Cruls alternam os tópicos referentes a uma e outra dessas duas realidades. `̀ concepção de um Brasil cindido entre litoral e sertão, associam-se questões de ordem psicológica gestadas em certos estratos sociais urbanos, que a formação médica do autor ajudou a perceber e a explorar em toda a sua obra ${ }^{3}$. Mas, em ambos os casos, é possível identificar, nas entrelinhas das diferentes tramas e enredos das suas primeiras narrativas, as aspirações e incertezas quanto a sua própria condição de escritor.

Uma compreensão mais adequada do processo de criação literária do autor no início de sua trajetória, por seu turno, deve não só identificar essas duas facetas a marcar o conjunto da sua obra, mas também pode ajudar a elucidar como se deu a articulação entre uma e outra e o modo como a Amazônia contribuiu para tais resoluções estilísticas. Ademais, nessa operação analítica, não devem ser negligenciadas as questões específicas a afetar um então aspirante a literato em busca de uma afirmação e consolidação como escritor. Os percalços enfrentados por Gastão Cruls ao decidir enveredar por uma carreira literária incerta, dentro de um contexto de mudanças políticas e culturais dos anos 1910 e 1920, geraram conflitos de toda ordem, principalmente com sua formação em medicina, fator decisivo para suas soluções literárias (Vívolo, 2017). Não é difícil identificar e avaliar o impacto de tais angústias do próprio autor nos contos e romances e nas soluções estilísticas encontradas. Além disso, tais conflitos e dilemas pessoais em muito podem revelar os escaninhos desse enfrentamento do autor consigo

${ }^{2}$ Sobre os modos de representação literária da paisagem natural no Brasil, ver Murari (2009). ${ }^{3} \mathrm{O}$ último romance de Cruls, De pai a filho, trata de assuntos relacionados ao desejo e da relação algo incestuosa entre mãe e filho. Ver Cruls (1954). 
mesmo e da sua inserção em um contexto de mudanças a afetar a própria produção literária do período.

As mudanças políticas e culturais pelas quais a sociedade brasileira passou ao longo dos anos 1920, por sua vez, foram fatores decisivos a interferir na gênese e na reconfiguração dos distintos grupos e cenáculos de intelectuais formados nos centros urbanos e nas próprias obras então produzidas (ver Miceli, 2001). A expansão urbana e a elevação substancial do número de leitores, bem como o aumento da circulação de jornais, principalmente na cidade do Rio de Janeiro, capital do país, converteramse em aspectos cruciais para a instauração paulatina de novas condições para o exercício do trabalho intelectual e para o redimensionamento da esfera pública ${ }^{4}$.

O acirramento do debate político, ao longo dos anos 1910 e 1920, acerca da necessidade de adoção de novas definições e delineamentos da nacionalidade - um debate ainda balizado pelos parâmetros da raça e do meio como fatores heurísticos válidos - ensejou intelectuais e literatos a buscarem alguma solução no sentido de viabilizar a afirmação de uma civilização brasileira. Desde a publicação de Os sertões, de Euclides da Cunha, quando uma população sertaneja foi não só vislumbrada, mas também delineada e caracterizada como portadora de uma autenticidade nacional, buscou-se conciliar tais elementos definidores de uma particularidade racial com os fatores ambientais representados pela singularidade da natureza no Brasil. Mas, dado o novo contexto histórico-cultural, tais fatores raciais e ambientais deveriam ser redimensionados. Daí a importância de um romance como Canaã, de Graça Aranha, e dos desdobramentos do modernismo e das vanguardas artísticas. Segundo a análise de Arnoni Prado (2010), no entanto, tais movimentos esbarraram em certas limitações políticas e

${ }^{4}$ Acerca da expansão dos centros urbanos e os seus efeitos sobre a vida do espírito ver Simmel (2013, p. 311-329). Sobre o conceito de espaço ou esfera pública no mundo burguês ver Habermas, 2003. Sobre a expansão e peculiaridade da atividade intelectual no Brasil, ver Miceli (2001). 
estéticas, precisamente em função da condição dos intelectuais naquele contexto de inícios do século $X X^{5}$.

\section{Medicina e literatura}

Quanto ao contexto intelectual, a trajetória literária de Gastão Cruls iniciou-se quando da querela ocorrida entre passadistas e modernos, ao longo dos anos 1910 e 1920 - uma conflagração marcada não só pelo polêmico debate acerca de uma linguagem mais ou menos apropriada a expressar a singularidade da realidade brasileira, mas também um embate destinado a redefinir o próprio papel dos intelectuais e da literatura dentro de um quadro político e cultural em mudança (Miceli, 2001; Prado, 2010). Filho primogênito do então renomado cientista belga Luís Cruls, Gastão perdeu precocemente seus irmãos mais novos, restando como único homem dentre quatro irmãs. A condição de primogênito fez com que a carreira científica do pai se vislumbrasse para ele como formação inevitável, embora a convivência familiar feminina o tenha, provavelmente, tornado um apreciador da literatura ${ }^{6}$. Fez o curso de medicina e, ainda recém-formado, desencantou-se com a profissão. Interessado desde cedo por literatura, escreveu e publicou seus primeiros contos com o pseudônimo de Sérgio Espínola na então prestigiosa Revista do Brasil, quando ainda dirigida por Monteiro Lobato ${ }^{7}$. Inicialmente alheio a qualquer cenáculo intelectual e literário, algo incomum para os aspirantes a uma carreira literária naquele ambiente cultural das primeiras décadas do século XX, Gastão Cruls manteve um contato próximo com Alberto Rangel desde cedo, mesmo antes de este último publicar seu Inferno verde. Os vínculos entre o pai de Gastão Cruls e Alberto Rangel remontavam à época da Escola Militar da Praia Vermelha.

${ }^{5}$ Ver também a análise comparativa de Sérgio Miceli acerca das vanguardas artísticas no Brasil e na Argentina (cf. Miceli, 2012).

${ }^{6}$ Os dados biográficos de Gastão Cruls aqui utilizados foram extraídos de Menezes (1978, p. 220) e Vívolo (2017).

${ }^{7}$ Acerca da importância da Revista do Brasil como instância de consagração intelectual e literária nos anos 1920, ver Miceli (2001). Para um entendimento dos dilemas de Gastão Cruls quanto à carreira literária, ver Vívolo (2017). 
Mas uma aproximação ainda mais estreita entre o filho do cientista belga e o autor de Inferno verde ocorreu quando da repercussão dos contos amazônicos de Alberto Rangel, um momento decisivo, portanto, para os possíveis rumos a serem seguidos pelo jovem médico ainda titubeante acerca de seu ingresso na carreira das letras.

A participação mais efetiva de Gastão Cruls em círculos literários ocorreu quando de sua aproximação com o grupo que girava em torno do escritor mineiro Antônio Torres, espécie de liderança intelectual de certa importância para as resoluções literárias iniciais de Cruls (cf. Cruls, 1950). Em 1920, juntou àqueles contos já divulgados na Revista do Brasil alguns outros, e publicou seu primeiro livro, Coivara, dedicado a Alberto Rangel. O termo "coivara" refere-se ao uso de ramagens em um processo de queimada de roçados com o objetivo de renovar a adubagem da terra, facilitando, assim, uma nova plantação. Desde então sua carreira como literato ganhou contornos mais nítidos e certa relevância. Em inícios dos anos 1930, com a expansão do mercado editorial, Gastão Cruls dirigiu o Boletim de Ariel que, posteriormente, tornou-se uma editora.

Do conjunto de contos desse primeiro livro de Gastão Cruls, é possível identificar uma miscelânea de temas abordados pelo autor. Temas a abarcar não só a paisagem e a vida sertaneja, embora seja um tópico recorrente na composição da sua obra como um todo, mas também temáticas atinentes ao contexto urbano. No entanto, chamam atenção os contos que revelam tanto um desencanto do autor com a carreira médica e suas práticas tidas como nefastas, quanto explicitam seus anseios a uma carreira literária, carreira essa concebida como uma vida dedicada à fruição estética. E é nesse sentido preciso que a influência de Oscar Wilde se faz presente. Saliente-se, igualmente, as apostas do autor em gêneros narrativos ainda não de todo corriqueiros naquele ambiente intelectual e literário de finais dos anos 1910. O recurso aos elementos do fantástico e do mistério impregnam tanto os contos a narrar tramas que se desdobram nos sertões quanto no cenário urbano. A temática da morte converte-se em eixo principal dos diferentes contos que estruturam o livro e, assim, pode ser tomado como 
um tópico expressivo a marcar uma transição entre a carreira médica a ser rejeitada e a vida literária incerta.

Quanto à linguagem, predominam nos contos de Coivara um estilo ainda passadista e certa tendência e apreço do autor pelo termo raro, próprio de um ambiente artístico e literário em transição entre uma tradição a reclamar seus direitos e um modernismo ainda não consolidado. Um período que foi definido por José Paulo Paes como art nouveau, uma terminologia que, segundo o crítico, seria mais adequada e precisa do que pré-modernismo (Paes, 1985) - um período artístico e literário marcado por uma linguagem rebuscada e altissonante a convergir sobre si mesma, embora utilizada de diferentes formas por autores distintos, desde Euclides da Cunha até Graça Aranha, passando por Coelho Neto e Alberto Rangel.

Estreitamente associada a essa literatura art nouveau, destaque-se a influência das obras de Oscar Wilde sobre muitos dos autores daquelas décadas de 1910 e 1920, inclusive sobre Gastão Cruls. Todos estavam imantados pelos princípios da "arte pela arte" propagados pelo autor irlandês. Os temas de mistério e os elementos fantásticos presentes nos contos de Coivara reverberam as concepções do autor de O retrato de Dorian Gray. Um dos contos desse livro de estreia de Gastão Cruls, "A noiva de Oscar Wilde", faz uma referência direta ao autor irlandês, atribuindo-lhe a existência de uma noiva brasileira e supostamente referida de maneira cifrada em seu livro escrito na prisão, De profundis (Cruls, 1922, p. 75-104). Para não aderir de todo ao argumento de Paes, destaque-se aqui a obra e a escrita de Lima Barreto, um autor pertencente a esse período e que se distanciava das influências de Oscar Wilde. O próprio Lima Barreto, nesse sentido, faz algumas restrições críticas aos contos de Coivara de Gastão Cruls por conta dessa presença excessiva do autor irlandês e, ao mesmo tempo, valoriza os contos que desvelam as mazelas e práticas médicas no Brasil ${ }^{8}$.

O conto Um asvero moderno, por sua vez, explicita a posição do próprio autor quanto ao seu desencanto com a medicina e os seus anseios por uma carreira literária. As exigências da carreira médica impõem um

${ }^{8}$ Ver o artigo de Lima Barreto sobre o livro de contos de Gastão Cruls (Barreto, 2017). 
estreito e permanente contato com as mazelas humanas, atando os pacientes ao médico de maneira inexorável e barrando ou dificultando qualquer possibilidade de fruição estética, aspecto tomado pelo personagem principal do conto como necessário para a própria existência.

Uma delimitação entre dois mundos incompatíveis é traçada no entrecho do conto a partir das agruras do Dr. Uchoa. O enredo deixa transparecer o esteticismo incorporado pelo autor e, ao mesmo tempo, concebe a carreira literária como descolada ou distanciada de preocupações ou exigências mais ordinárias e rebaixadas, tais como aquelas impostas pela carreira médica. A trajetória de um médico pouco convicto da sua vocação, além de bastante arredio em relação às mazelas humanas, contrasta com a sua personalidade sensível a ansiar por uma vida esteticamente prazerosa. O fato de a ambiência do entrecho do conto ser no Japão, local onde o médico havia se refugiado de maneira segura de seus pacientes, a ponto de naturalizar-se japonês e transformar-se em negociante de objetos de arte, faz com que o narrador do conto se refira à arte nipônica como exemplo extremado de a estética constituir-se, por si só, como um mundo à parte, um mundo a ser vivido por aqueles que não se enquadram em profissão alguma.

\section{Sertão e interioridade}

Em inícios dos anos 1920, ainda no exercício pleno da medicina, Gastão Cruls fez parte da Comissão de Saneamento Rural que visitou o interior do Estado da Paraíba. Dessa sua viagem pelo sertão nordestino o autor pôde observar mais proximamente o modo de vida dos sertanejos e, assim, manter um contato mais estreito com a paisagem árida da caatinga. O seu segundo livro de contos, Ao embalo da rede, de 1923, aproveita-se dessa experiência, embora mantenha em seu conjunto certa mescla de temas voltados tanto para os sertões quanto para questões relativas ao meio urbano. Mesmo nos contos que abordam a paisagem e a vida sertaneja, o 
autor promove um entrelaçamento entre os dois cenários ao enredar na mesma trama personagens de um e de outro ambiente.

No conto Flor de tabuleiro, que abre o livro, o enredo é desdobrado a partir das vozes de dois narradores. O narrador principal, um médico pertencente a uma Comissão de Saneamento destinada a fazer inspeções naquela área do sertão, espécie de alter ego do autor, e um narrador secundário, o sertanejo Pádua, que serve de guia para o médico e seu companheiro engenheiro, também membro da tal comissão. Na medida em que os três personagens cruzavam a caatinga, descrita e caracterizada como uma paisagem seca com vegetação esturricada, os dois visitantes alegaram a possibilidade de perda de orientação para qualquer viajante que trilhasse aqueles caminhos sempre iguais. O guia sertanejo, no entanto, assegurou que, a despeito de uma aparente mesmice da paisagem, a vegetação ali existente servia como referência para o rumo correto a ser tomado, sem riscos de desvios. Os dois visitantes, no entanto, não se convenceram, e permaneceram um tanto quanto aturdidos com a hostilidade que o ambiente impunha. Mas, aos olhos do sertanejo, a paisagem seca da região se apresentava de maneira singular e em toda a sua diversidade vegetal. O narrador principal do conto descreve a paisagem sertaneja e exterioriza os seus temores:

Tal era, porém, a monotonia da paisagem, a repetir-se desoladoramente numa sucessão de aspectos sempre idênticos que, por vezes, a despeito da marcha dos animais, eu me acreditava também especado ao solo e para sempre perdido na planura intérmina, como um daqueles muitos arbustos, esgalhados e hirtos que, à torreira do sol, se desseivavam na maninhez do areal adusto (Cruls, 1923, p. 13).

Quando do comentário do visitante acerca da suposta homogeneidade da paisagem, o guia sertanejo reage e surpreende o médico com a sua capacidade de identificar em minúcias aquela vegetação aparentemente morta e igual: 
- Mas, Sr. Pádua, isto aqui é tudo igual...

- Igual o que, seu doutor! É o que parece. Para mim todos estes pés de pau são diferentes.

E o Sr. Pádua, correndo as esporas no seu ruço-pombo, passou a trotar ao meu lado para nomear todas as plantas que formavam naquele mato ralo e definhante: aqui, um cajueiro bravo e, logo a seguir, algumas mangabeiras; ali, uma touça de marmeleiros, sobranceada por um espinho-rei; acolá, sobre uns lajeiros, macambiras e gravatás espinhosos; mais adiante, um grupo de muricis e alguns pés de batiputá; e mais cajueiros bravos e outras mangabeiras; e ainda agora novos marmeleiros, que se sucediam à orla da estrada. Tudo aquilo, porém, sem a alegria de uma flor. Uma vegetação esquálida e praguejada, desbotando-se às inclemências do sol (Cruls, 1923, p 16, grifos meus)

Uma sensação de desconforto parecia se abater sobre os visitantes naquele ambiente seco e aparentemente sem vida da caatinga. A incapacidade demonstrada pelos membros da Comissão de Saneamento em perceber a variedade da vegetação ali existente, tal como o sertanejo havia identificado, tende a acentuar não só a distância a separar o sertão longínquo e isolado do ambiente urbano dos viajantes, mas também indica as barreiras e dificuldades existentes para uma decifração dos sinais e indícios para uma compreensão adequada daquela realidade árida. A decifração de sinais, contudo, é um tema que se desdobra no entrecho do conto. Para provar e ressaltar a sua capacidade em identificar com precisão aquela vegetação aparentemente homogênea, com árvores ressequidas e sem flores, o sertanejo Pádua relatou aos viajantes a tragédia de Anunciata, uma menina por ele encontrada naquelas paragens, solitária, e que já havia sido apresentada em viagem anterior ao médico visitante, que então ficara impressionado com a sua beleza. Segundo Pádua, ela havia fugido de casa por conta dos maus-tratos infligidos pela mãe. Ao levá-la, no entanto, o sertanejo se viu obrigado a quebrar a resistência de sua mulher, pois esta antevia maus presságios com a presença da menina em sua casa. 
Por conta de um filho já adolescente, Gabriel, a mulher de Pádua previa que aquela menina logo seria mulher. Os "olhos de xexéu" da menina não eram indicativos de bom agouro, alegava a mulher do sertanejo ${ }^{9}$. Segundo as crendices da caatinga, "olhos azuis" pressagiavam má sorte. (Tal referência aos olhos azuis agourentos do japiim aparecem em outros contos e romances de Gastão Cruls, talvez uma referência negativa no que diz respeito a sua própria condição de médico a dedicar-se à literatura. Cruls, filho de estrangeiro, tinha olhos azuis).

Com o passar do tempo, continuou o sertanejo a relatar a tragédia, e tendo em vista a morte do pai de origem italiana, a menina foi abrigada e adotada por ele como filha, a despeito dos avisos e receios da mulher. Ao crescer, ambos, Anunciata e Gabriel, tal como previsto, enamoraram-se. Dada a reação dele, Pádua, em não permitir aquele relacionamento entre irmãos, Anunciata fugiu de casa. Foi encontrada morta, tempos depois, enforcada ao pé de uma daquelas árvores ressequidas localizada justamente naquele caminho por onde os visitantes passavam. Quando do retorno do sertanejo para casa a fim de notificar a mulher sobre o ocorrido, soube que o filho Gabriel havia se matado com um tiro na cabeça.

O desfecho trágico da história impactou e emudeceu os dois visitantes, como se aquela paisagem esturricada e aparentemente morta do sertão fosse transfigurada no decorrer da narrativa em um espelhamento de seus próprios sentimentos. Restou ao narrador principal, o médico, salientar o fato de a tragédia ter ocorrido naquele ambiente de árvores galhadas, com o corpo de Anunciata dependurado em uma delas como se a beleza da menina representasse, de alguma forma, uma floração inusitada. O conto aponta para a capacidade de apreensão dos sinais não só fornecidos pela vegetação da caatinga a viabilizar um esquadrinhamento da paisagem sertaneja e de suas veredas, como Pádua havia demonstrado, mas também dos indícios fornecidos pelos pássaros e animais a evidenciar riscos e perigos reservados pelo destino ao longo do tempo, tal como a mulher do sertanejo intuíra. Vale lembrar que a prática médica e a própria psicanálise

${ }^{9}$ Xexéu é o outro nome pelo qual é conhecido o japiim. 
estão diretamente relacionadas aos mesmos princípios de decifração de sinais e indícios para proferir um diagnóstico adequado dos pacientes (Ginzburg, 2007). Mas aquela natureza dos confins do sertão nordestino não se apresentava traduzível para o médico visitante.

A presença de Gastão Cruls na região da caatinga durante a sua participação na Comissão de Saneamento reforçou a existência da temática sertaneja em seus contos iniciais, porém, não exatamente nos mesmos moldes como se apresentava dentro de uma tradição regionalista firmada desde finais do século XIX. Como já salientado, à medida que a urbanização se desdobrava como um processo novo no Brasil de inícios do século XX, o modo de representação literária da realidade sertaneja também tendia a se modificar. A tematização de tópicos como a morte, o mistério e o fantástico e, de alguma forma, a ficção científica, tal como explorados por diferentes autores do período (ver Lobato, 2009), viabilizou a presença e o realce nas narrativas de Gastão Cruls de aspectos psicológicos, arrefecendo os efeitos apenas exóticos de uma paisagem a ser descrita. Como no conto Flor do tabuleiro, o ambiente ressequido da caatinga ganha contornos mais bem delineados quando da reação muda dos personagens à tragédia de Anunciata, com a sua imagem projetada em uma daquelas árvores galhadas, dependurada tal como uma flor solitária.

Considerando-se a Amazônia como uma região abarcada pelos vastos sertões brasileiros, uma breve comparação entre um dos contos de Alberto Rangel em Inferno verde, Maibi, e o conto Flor do tabuleiro pode revelar não só uma possível influência de um autor sobre o outro nesse início de carreira literária do jovem médico, mas também ressaltar modos de figuração distintos entre ambos, na medida em que os propósitos se diferenciam em um e em outro quanto a uma apreensão da paisagem e da natureza. Embora atrelado a uma tradição literária já consolidada acerca de uma figuração dos sertões, Gastão Cruls também parece distanciar-se dela. No conto de Alberto Rangel, a personagem Maibi é utilizada como "moeda de troca" para saldar a dívida de Sabino, seu marido, um dos poucos seringueiros a possuir mulher e um dos muitos endividados a habitar os confins da 
Amazônia. Ao "repassar" a própria mulher para outro seringueiro como forma de quitação de saldo, tudo intermediado pelo proprietário do seringal, Sabino não se consola com essa negociação um tanto quanto esdrúxula, embora corriqueira naqueles ermos amazônicos, e decide vingar-se. Rapta Maibi de seu novo parceiro e a amarra em uma seringueira, cravando-lhe no corpo as tigelas então utilizadas para coletar o látex. Embora a ação vingadora de Sabino tenha sido motivada pelos desvarios da paixão, como salienta o narrador do conto, a imagem bizarra da cabocla Maibi amarrada à seringueira e cravejada de tigelas a recolher o sangue a jorrar de sua "carne acanelada" seria a síntese da própria Amazônia em processo de destruição por conta da cobiça da borracha.

A comparação do corpo sacrificado de Maibi com uma orquídea que teria florido na seringueira, por sua vez, não só reforça o aspecto sexual implicado na tragédia, mas também salienta a natureza como parâmetro explicativo por parte do autor para uma compreensão dos problemas sociais e econômicos da região. Não há no conto de Alberto Rangel uma preocupação em salientar a dimensão psicológica dos personagens envolvidos na trama trágica a afetar os seringueiros isolados em plena selva. Sua mira volta-se para aspectos mais abrangentes ao esquadrinhar a região amazônica dentro de um panorama político mais geral. Maibi e Anunciata, duas orquídeas que correspondem a formas distintas de expressão da realidade sertaneja, a despeito das diferenças existentes entre a selva amazônica e a caatinga do Nordeste, foram concebidas a partir de perspectivas diferenciadas: Maibi como denúncia socioeconômica, Anunciata como uma inadequação de ordem psicológica a espelhar-se no ambiente.

\section{Nos confins do psiquismo}

A Amazônia, por sua vez, também se faz presente nesse segundo livro de contos de Gastão Cruls. Embora seja referida de maneira apenas lateral, é possível identificar a presença da região e um diálogo entre o autor de Ao embalo da rede e a perspectiva "infernista" de Alberto Rangel acerca da 
Amazônia. O conto $O$ abcesso de fixação do livro de Gastão Cruls reforça, nesse sentido, o seu modo peculiar de abordar a natureza e a paisagem dos sertões brasileiros ao tomar como foco privilegiado de suas narrativas a dimensão psicológica dos personagens. É a partir de aspectos e dramas psicológicos vivenciados pelos personagens nas tramas que a natureza ganha contornos bastante específicos.

O conto narra o encontro entre dois médicos embarcados em um navio no Rio de Janeiro em viagem rumo ao norte do país. Um deles, o narrador do conto, tem como destino o Nordeste, e seu companheiro de quarto, de nome estrangeirado, Christian Thompson, destina-se a Manaus. Dadas as aparentes afinidades profissionais e de personalidade, uma empatia logo se estabeleceu entre os dois viajantes a ponto de ambos isolarem-se dos demais passageiros. O narrador logo percebeu a personalidade ensimesmada e retraída de seu companheiro de quarto, sempre isolado e a ler Crime e castigo, de Dostoievski. Ele próprio também tendia a um comportamento isolado quando em viagem, e mergulhado na leitura de Proust. Das conversas então entabuladas entre os dois no passadiço do navio, o Dr. Thompson revelou residir no exterior já há algum tempo, e relatou os motivos que o trouxeram de volta ao Brasil e da sua ida a Manaus: tratar da venda de umas terras que haviam se valorizado naqueles ermos amazônicos.

Quando da proximidade do desembarque em Recife, no entanto, e tendo em vista o consumo a mais de whisky por parte do misterioso Dr. Thompson, o narrador relatou ao seu curioso interlocutor aspectos da sua vida e de suas atividades profissionais. Ele já havia trabalhado, por exemplo, como médico socorrista, ou seja, prestava assistência em eventuais casos de urgência como médico plantonista. Ao saber disso, o Dr. Thompson logo demonstrou um interesse mais agudo pelas histórias certamente vividas pelo médico quando das diversas ocorrências a que se viu obrigado a atender. Segundo ele, Ihe causava certo frisson ouvir histórias marcadas pela morbidez e pelo horror que invariavelmente estavam implicadas nas ocorrências. 
O efeito do álcool no Dr. Thompson parecia trazer à tona uma outra personalidade que the era normalmente oculta. Dualidade de personalidade que parecia cindir o mesmo ser entre o taciturno e ensimesmado passageiro sempre isolado e aquele outro, um ansioso palrador ávido por histórias mórbidas em busca de um frisson ${ }^{10}$. Quando o narrador do conto recordou de um caso específico e intrigante que ele havia atendido na época da sua atividade como médico socorrista, o assassinato de uma prostituta de nome Sarah, o Dr. Thompson logo acusou lembrar-se plenamente do caso, pois ainda residia na cidade do Rio de Janeiro na época. Até salientou, para surpresa do narrador, que se tratava de uma polaca de sobrenome Itanovicht. De imediato o Dr. Thompson esclareceu que a lembrança de tais detalhes do caso se dava em função da ampla cobertura feita pela imprensa, inclusive que o criminoso não havia sido identificado. Quando o narrador esmiuçou os detalhes daquela ocorrência, a posição do corpo da vítima sobre a cama no pequeno aposento, o ferimento à faca desferido contra a prostituta, o Dr. Thompson não se conteve e confessou, para surpresa de seu interlocutor, ter sido ele o autor do crime, do assassinato de Sarah Itanovicht.

No entanto, o mais surpreendente daquela revelação inusitada durante uma conversa entre médicos no tombadilho de um navio foram os motivos alegados pelo Dr. Thompson para o cometimento do crime. A sua vida profissional como médico, desde o começo da carreira, foi tragicamente marcada pela morte de uma jovem paciente que chegou ao óbito sem que ele pudesse dar um diagnóstico adequado e, portanto, sem prescrever os eventuais remédios para a cura da doença. Essa culpa, relatou o Dr. Thompson, o teria perseguido ao longo de anos, transmutando-se em

${ }^{10} \mathrm{O}$ problema do duplo é uma questão recorrente na obra de Gastão Cruls. Pode-se dizer que é quase um eixo estruturante de seu processo criativo. Tal temática aparecerá de maneira mais explícita em seu segundo romance, Elza e Helena, de 1927, no romance experimental A criação e o criador, de 1928, e Vertigem, de 1934. Se desdobrará também em seu último romance de 1954, De pai a filho. Mas também é possível identificar a presença do duplo em seu primeiro romance, A Amazônia misteriosa, de 1925. 
uma espécie de neurastenia a interferir diretamente na sua vida pessoal e profissional.

A internalização da culpa pela morte da jovem paciente e a sua consequente evolução para uma neurastenia descambou, ao fim e ao cabo, em pensamentos mórbidos de suicídio como única saída para solucionar um drama de consciência.

Essas coisas, que noutra ocasião não teriam para mim a menor importância, não sei se devido ao estágio de fadiga extrema em que me achava, começaram a calar no meu espírito e o foram minando de tal forma que um dia - o dia a que já me referi - também comecei a desconfiar da minha culpabilidade. Foi o quanto bastou. Daí por diante não tive mais sossego e foi como se mãos invisíveis e diabólicas houvessem remexido no meu cérebro, destruindo os elementos mais nobres, afugentando os pensamentos bons e apagando todas as recordações felizes do passado, para trazer à tona a vasa humana do subconsciente, onde rastejam as larvas do crime e da loucura. Sim, meu amigo, pensei ter enlouquecido, e foi por isso que estive longo tempo a acariciar o cabo do revólver. Na ideia do suicídio, encontrei, porém, uma nova fonte de sofrimentos, pois que me faltava a coragem para executá-lo e uma voz persuasiva clamava alto aos meus ouvidos que eu era inocente e não devia obedecer aos ditames da minha consciência (Cruls, 1923, p. 128).

Diferentemente das resoluções literárias corriqueiras e então propagadas pela escola naturalista de finais do século XIX, e considerando-se, de maneira mais destacada, o modo como a estética naturalista foi adaptada à realidade brasileira (Candido, 1998), o autor não estabelece no entrecho do conto uma relação direta entre as perturbações e os distúrbios psicológicos do médico/assassino com aspectos de ordem fisiológica ou com a singularidade da natureza do país (talvez decorra daí a decisão do autor em atribuir um nome estrangeiro ao personagem). A dimensão propriamente psicológica é ressaltada pelo autor como uma entidade relativamente autônoma, responsável única e direta pelo mal-estar que gradualmente passou a perturbar o personagem. A angústia e os pensamentos mórbidos de suicídio que então afetaram o Dr. Thompson são descritos na narrativa como pensamentos em "carne viva", ideias concebidas pelo agulhão da dor 
"como se o cérebro estivesse a descoberto e os pensamentos percorressem nervos esfolados" (Cruls, 1923, p. 130). Embora o autor faça uso de uma retórica a reverberar referências fisiológicas, o intento buscado é conferir uma relevância maior para as perturbações e dramas psicológicos do médico e assassino. As referências ao romance de Dostoievski, Crime e castigo, e a Marcel Proust almejam ser um reforço para o alcance de tais objetivos, ou seja, apartar a dimensão psicológica de questões outras relacionadas ao aspecto fisiológico e da natureza.

A cura encontrada pelo médico para as perturbações psicológicas, por seu turno, seguiu os preceitos fornecidos pela própria medicina e foram transpostos e aplicados ao plano psicológico, ou seja, segundo o relato do Dr. Thompson, havia um procedimento já antigo adotado pela medicina: quando um determinado corpo está a sofrer uma infecção generalizada, buscava-se concentrar a circulação dos germes pelo corpo em um determinado ponto, criando-se um abcesso. Um "abcesso de fixação", portanto, era um meio terapêutico utilizado para a cura de infecções generalizadas quando da concentração dos germes em um ponto específico do corpo. Caso esse raciocínio fosse desdobrado para o plano dos distúrbios psicológicos, ressaltou o Dr. Thompson, ele poderia livrar-se de seus pensamentos mórbidos já incontroláveis ao concentrar todos eles em um só. O projeto de um assassinato surgiu precisamente da transplantação, por analogia, de procedimentos adotados no âmbito fisiológico para o psicológico.

Após um planejamento minucioso, o crime foi perpetrado e, dadas as circunstâncias, a tal prostituta foi tomada como a vítima mais adequada. $\mathrm{O}$ Dr. Thompson, e diferentemente do personagem de Dostoievski em Crime e castigo, alegou os efeitos benéficos quase imediatos do crime em relação a suas perturbações psicológicas. Como tinha agora que se dedicar a não ser identificado como o assassino da prostituta, tal preocupação eliminou os pensamentos de culpa que o induziam ao cometimento do suicídio. Embora as investigações do crime, em momento algum, o houvessem colocado sob a condição de eventual suspeito, o Dr. Thompson tomou 
a decisão de sair do Rio de Janeiro e refugiar-se nos ermos amazônicos, voltando-se para os afazeres próprios da extração do látex.

O isolamento nos rincões amazônicos converteu-se, portanto, em uma maneira radical de apartar os dois momentos da sua vida até ali. Ao finalizar o seu relato, o Dr. Thompson pergunta ao seu interlocutor, e também médico (uma espécie de alter ego do autor), se ele não faria a mesma coisa, ou seja, se as perturbações psicológicas que eventualmente venham a afetar alguém não deveriam ser solucionadas por meio desse artifício, de uma busca por um "abcesso de fixação", mesmo considerandose o sacrifício da carreira médica. Caso tomemos esse momento inicial da trajetória literária de Gastão Cruls, um médico recém-formado e um tanto quanto desiludido com a carreira, o fato de o conto ter sido escrito, por si só, talvez tenha representado uma maneira de equacionar a sua própria condição a sofrer os percalços e a culpa de uma cisão entre a medicina e a literatura. O personagem e narrador de seu primeiro romance, vale ressaltar, também decidiu refugiar-se na Amazônia.

\section{Amazônia: veredas do imaginário}

A publicação, em 1925, de A Amazônia misteriosa deve ser considerada um importante ponto de inflexão na carreira de Gastão Cruls, e isso na medida em que o romance como gênero literário peculiar exige do autor outro tipo de investimento e de compromisso com o próprio fazer literário. Pode-se dizer, ainda, que essa obra sintetiza aquelas duas vertentes que já se faziam presentes nos diversos contos até então publicados pelo autor em seus dois livros iniciais: os dilemas e dramas de ordem psicológica a afetar os diferentes personagens, de um lado, e a tradição literária acerca da abordagem dos sertões e da natureza no Brasil, de outro. A Amazônia configurou-se para o autor como uma região propícia a viabilizar a confluência daquelas duas vertentes, tanto em função de uma presença opressiva da natureza quanto pelo modo como essa opressão pode ser psicologicamente aproveitada do ponto de vista dos dramas humanos. 
Diferentemente da paisagem do sertão nordestino, o autor ainda não conhecia in loco o ambiente amazônico quando da sua decisão de escrever o seu primeiro romance. Somente em 1928, quando da sua participação na expedição chefiada por Cândido Rondon, e então destinada a estabelecer os limites do Brasil com a Guiana Holandesa, é que o autor conheceu a região e resolveu publicar A Amazônia que eu vi, em 1930. Uma obra deliberadamente concebida em um formato de diário de viagem, embora carregada de referências literárias.

Como já salientado, não seria despropositado identificar no primeiro romance de Gastão Cruls certos modos de figuração da Amazônia já delineados, por exemplo, nos contos de Inferno verde, de Alberto Rangel, e em todo um imaginário devidamente consolidado até então sobre a região. Mas a ausência de uma vivência do ambiente amazônico impôs ao autor a necessidade de outras soluções para a construção do romance ${ }^{11}$. Ao realismo próprio de um diário de viagem, associou-se o lendário das "guerreiras Amazonas" e do "País das pedras verdes". Ao primitivismo e barbarismo atribuídos às populações indígenas da região contrapôs-se certo grau de civilização já atingido pelas populações pré-colombianas. Um romance, portanto, destinado a abordar a Amazônia como uma região geograficamente delimitada, mas uma abordagem que se fez por meio do seu imaginário.

Ao examinar-se o modo como o romance foi armado e sua trama tecida, é possível identificar não só os marcos de uma tradição quanto aos processos de representação da Amazônia que se consolidaram ao longo do tempo, mas também como tal tradição pôde ser articulada com novas formas de expressão literária próprias de um ambiente urbano já em expansão

\footnotetext{
${ }^{11}$ Para escrever seu primeiro romance sobre uma região por ele até então desconhecida, Gastão Cruls empenhou-se em uma pesquisa minuciosa em bibliotecas e livrarias, escarafunchando metodicamente todo tipo de informação, de relatos de viagem até a fauna e flora amazônicas. Do volume de informações acumuladas, o autor de A Amazônia misteriosa publicou, em 1944, Hileia amazônica (cf. Cruls, 1950).
} 
no Brasil dos anos 1920: a literatura fantástica e a ficção científica ${ }^{12}$. Um modo de representação literária da Amazônia, vale ressaltar, forjado a partir tanto dos relatos de viajantes e exploradores dos séculos XVI e XVII, preocupados em fornecer um sentido e um enredo para a região (Gondim, 1994), quanto das investigações de cientistas/naturalistas dos séculos XVIII e XIX, dedicados a deslindar a fauna e a flora de uma natureza concebida como excessiva e opressora. Se os escritos de Euclides da Cunha e Alberto Rangel interferiram mais diretamente na linguagem um tanto rebuscada de Gastão Cruls sobre a Amazônia, ele soube agregar a tais demarcações de um imaginário regional os ganhos e os contornos propiciados pela ficção científica de autores como Conan Doyle, em $\mathrm{O}$ mundo perdido, e de $\mathrm{H}$. G. Wells, em A ilha do dr. Moreau.

Mas o enredo de A Amazônia misteriosa, a despeito da centralidade do tema amazônico, deixa transparecer os dilemas do próprio autor quanto às decepções de uma carreira médica e as apostas que o romance em si poderia representar como afirmação de uma carreira literária. A contraposição entre ciência e literatura converte-se em uma espécie de fio condutor da trama ao colocar sob suspeição a racionalidade fria do conhecimento cientifico como eventual sinal de progresso civilizacional. Tal embate, para além de uma possível referência e crítica aos acontecimentos de meados e final da década de 1910, quando da eclosão e desfecho da I Guerra Mundial, também revela o projeto do autor em deslocar uma visão pretensamente objetiva da realidade amazônica para uma perspectiva subjetiva. Não que a perspectiva subjetiva da realidade implicasse algum tipo de alheamento do mundo, mas sim, ao revés, por ser justamente uma perspectiva destinada a reforçar o fato de a realidade ser dotada de algum sentido somente pela via de uma visão interiorizada. Portanto, o autor faz uma crítica tanto à ciência como uma instância aferrada a procedimentos e experiências comandadas

${ }^{12} \mathrm{O}$ primeiro romance de Monteiro Lobato, O presidente negro, publicado em 1926, é um romance de ficção científica que, ao tratar da questão racial e dos supostos malefícios que poderiam ser acarretados com a miscigenação, também tematizam a questão da urbanização e da literatura de um ponto de vista de quem inicia uma carreira literária (cf. Lobato, 2009). 
por princípios tomados como racionais, e que desembocam, invariavelmente, em opressão e desumanidade, quanto reivindica a sensibilidade como meio decisivo a ligar a subjetividade ao mundo exterior. Nesse sentido, a questão da violência e do embate travado entre grupos humanos, por exemplo, não foi devidamente equacionada, mesmo considerando-se os avanços e conquistas da ciência. $\mathrm{O}$ autor parece insinuar que um verdadeiro entendimento civilizacional só poderia ser alcançado pela via da valorização da arte e da literatura.

Ora, tal como em O mundo perdido, de Conan Doyle, a violência predomina tanto no mundo pré-histórico descoberto em um platô na Amazônia quanto nos salões de debate científico de Londres. A similaridade física entre o Dr. Challenger, um cientista irascível e antissocial que constatou a existência de animais pré-históricos, e o líder dos antropoides encontrados naquele vale perdido, reforçam o traço da violência como marca própria das sociedades humanas, tanto no passado mais longínquo quanto no presente (Doyle, 1982). Da mesma forma, o paralelo entre o romance de Gastão Cruls e o de H. G. Wells, A ilha do Dr. Moreau, ressalta esse juízo condenatório da ciência quando o cientista e protagonista da trama amazônica, o alemão Hartmann, se arvora a alterar a própria ordem da natureza por meio de seus experimentos biológicos. Experimentos destinados a criar novas espécies de animais a partir daqueles já conhecidos e, assim, perpetrar uma dominação absoluta do homem sobre a natureza, da razão sobre os instintos. Ora, se o imaginário acerca da Amazônia sempre a definiu como um espaço onde a natureza prepondera, uma região, portanto, alheada do mundo civilizado europeu, ela se converte em um ambiente permissivo para um livre exercício de experimentos científicos condenados em sociedades mais civilizadas. E é precisamente nesse sentido que o tema racial também ganha destaque na trama de A Amazônia misteriosa, um tema caro para o pensamento social no Brasil desde o final do século XIX (Schwarcz, 2011). Mas, diferentemente do romance de Monteiro Lobato, por exemplo, Gastão Cruls não condena a mestiçagem, embora os parâmetros raciais continuem a demarcar o modo de pensar dentro daquele contexto histórico e cultural. 
O romance inicia com as últimas anotações em um diário de viagem de um médico, e também narrador da trama, então a vagar pelos ermos amazônicos. Embora os motivos da viagem não sejam revelados, sabe-se que o médico/narrador lidera uma comitiva formada por diferentes membros e ajudantes, alguns nordestinos migrados e outros caboclos nativos da região, portanto, personagens a representar os sertanejos do interior do Brasil. Já nesse momento inicial da narrativa é possível perceber o quanto os relatos de viajantes e naturalistas converteram-se em material para o autor fabular acerca da Amazônia.

[...] Hoje, pela primeira vez, dei razão a Agassiz, quando fala na "monotonia triste e enfadonha" das paisagens amazônicas. É verdade que, mais do que nunca, estamos agora, num trecho em que o rio é tortuoso e a floresta, fechada e opressiva, nos cerca por todos os lados. Uma ou outra árvore florida, ou a plumagem brilhante de qualquer pássaro são incidentes mínimos e sem nenhum relevo, quando se tem diante dos olhos a amplidão do mataréu sem fim. Nem mesmo há aqui a gradação dos verdes. Uma única e mesma tinta sombria empasta toda a vegetação, das frondes altanadas às plantas mais mofinas. Até as palmeiras, em outros pontos de uma pujança e variedade incríveis, uniformizam-se aqui nas tristonhas jarás, de palmas ralas e estios delgados (Cruls, s/d, p. 17).

A dimensão agigantada da floresta oprime o homem. A monotonia de uma paisagem sempre verde, sem maiores variações de tonalidade, impõe certa melancolia para aqueles que ousam trafegar pelos seus caminhos tortuosos e labirínticos. É uma visão da Amazônia deliberadamente tomada de empréstimo dos relatos de viajantes e naturalistas. O diário de viagem converte-se em estratagema narrativo destinado a atenuar a perspectiva de uma região vislumbrada por olhos alheios. Mas também é possível identificar os pontos de vista dos demais membros da comitiva acerca daquela realidade singular, mesmo que filtrados pela voz do narrador. Como é um grupo formado por nordestinos migrados e caboclos da região, vez ou outra ocorrem entreveros entre uns e outros acerca dos caminhos a serem trilhados ou do pitoresco da fauna e da flora regionais. O nordestino 
Pacatuba ganha realce como personagem em função de desempenhar o papel de um interlocutor estratégico do narrador. As constantes referências que Pacatuba faz aos costumes e à natureza árida nordestina viabilizam ao narrador uma comparação e um contraste permanente entre as duas regiões. O realismo, nesse sentido, parece ter imposto essa estratégia dialógica com a finalidade de camuflar o desconhecimento do autor acerca da paisagem amazônica, a despeito de estar fortemente ancorado nas leituras dos relatos de viajantes e naturalistas.

Ora, o diário de viagem converte-se em recurso eficaz e destinado a propiciar a passagem do romance assentado em um realismo documental para ingressar no imaginário amazônico. Já no segundo capítulo, quando se sabe que três membros do grupo se perderam na floresta, o relato passa a ser feito pela voz do narrador, mas não mais na forma de um diário de viagem. Embora a voz seja a mesma, o formato é outro e a credibilidade do narrador parece assegurada ${ }^{13}$.

A inserção no mundo mítico e lendário da Amazônia ocorre quando três dos componentes da comitiva se perdem nas brenhas da mata: o médico/narrador, Pacatuba e Piauí, este último já veterano em percorrer os intrincados caminhos da floresta. O percurso oferecido por determinada trilha na selva faz com que a vegetação dominante ganhe contornos de um mundo habitado por gigantes.

Sumaumeiras gigantescas, tocaris hercúleos, majestosos cedros, abrindo as ramas no alto, faziam o travejamento desse maciço zimbório de verdura, que transverberava claridade vaga, deixando o recesso da mata num crepúsculo esverdeado. Aí, numa luta surda, mas de todos os instantes comprimiase, amotinada, a legião sem fim dos outros vegetais. Árvores portentosas confundindo raízes e sapopemas na difícil conquista do solo; troncos seculares abarcados por cipós constritores, copagens grenhudas entretecidas de monstruosas trepadeiras; forquilhas cravejadas de caraguatás e parasitas; moitas espessas de palmeiras; tufos sombrios de folhagens; estolhos aculeados e refilhos gavinhentos rojando pelo chão, unhando a galharia, engrimpando-se nos ramos; hastes colubreantes, volutas sarmentosas e redouças virentes; - tudo

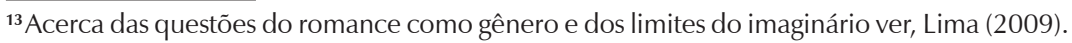


aquilo revolto, emaranhado, inóspito, mas borbulhando viço e regorgitante de selva, na "frescura eterna da vida orgânica", subia às avançadas para o azul, num mesmo anseio de luz (Cruls, s/d, p. 30).

A descrição da floresta por meio de um palavreado a ressaltar certa exuberância da paisagem não só confirma as contaminações de uma linguagem tortuosa e grandiloquente de autores que se debruçaram sobre a realidade amazônica, mas também denuncia certas limitações do autor em retratar o ambiente e a natureza daquelas paragens do Brasil. $\mathrm{O}$ recurso a termos esdrúxulos faz revelar um esforço do autor em suplantar uma visada apenas indireta da região, além de realçar a sua especificidade como uma realidade dominada pela vegetação. Se nos contos de Coivara e de Ao embalo da rede a busca pelo termo raro já se apresentava como uma característica da literatura de Gastão Cruls, em muitas passagens do seu romance amazônico essa linguagem rebuscada é exercitada ao exagero, como se a singularidade da região assim o exigisse. $\mathrm{O}$ autor parece almejar, por meio da linguagem, maior eficácia para delinear de maneira convincente uma realidade não conhecida, deliberadamente borrando a pintura pelo excesso de tinta.

Ora, a fonte então disponível para que uma visão de segunda mão da região fosse retrabalhada era a própria literatura, ficcional ou não. A Amazônia a ser mapeada pelo autor, portanto, não é uma região geograficamente definida a partir da configuração da sua natureza, a despeito dos esforços de descrição e de usos abusivos de termos regionais ${ }^{\mathbf{1 4}}$, mas uma Amazônia fabulada pelos próprios relatos de viajantes e naturalistas ou pelas lendas e mitos que cercam a região desde o início de sua exploração. Como apontado por Gondim (1994), mesmo os relatos dos primeiros viajantes e exploradores da região já estavam contaminados pelas lendas oriundas do Oriente, tornadas conhecidas no mundo europeu a partir da viagem de Marco Polo.

${ }^{14}$ Ao final do romance de Gastão Cruls existe um "Elucidário" com os termos regionais utilizados no decorrer do romance (cf. Cruls, s/d, p. 224-36). 
Dadas as insuficiências e restrições impostas pela linguagem manejada pelo autor, inviabilizando, assim, qualquer tentativa mais ousada do ponto de vista formal do romance, restou a associação entre os relatos de viajantes e aqueles outros recursos já utilizados nos contos, ou seja, o fantástico, agora acrescido por elementos da ficção científica. Aos experimentos biológicos de um cientista alemão ávido em criar novas espécies (um Dr. Moreau na Amazônia), acoplou-se a lenda das "guerreiras Amazonas" e do "País das pedras verdes". O contraste entre o aspecto fantástico da trama, de um lado, e os relatos e referências de viajantes e naturalistas, de outro, converteu-se em uma saída possível para o autor em termos de um formato para a obra.

Mas, por seu turno, também é possível identificar as angústias do próprio Gastão Cruls no modo como aquela descrição da selva acima citada foi concebida e construída. A perspectiva da floresta é delineada a partir de uma visão de baixo, de alguém a se posicionar de maneira apequenada diante do gigantismo das árvores e das folhagens em permanente "luta surda". O próprio Gastão Cruls, nesse sentido, ainda se encontrava em uma situação a enfrentar desafios em um ambiente intelectual marcado por disputas e confrontos, como já se configurava o ambiente literário na cidade do Rio de Janeiro dos anos 1920. Se nos contos de Alberto Rangel, em Inferno verde, é possível identificar nas suas referências à vegetação amazônica as barreiras e os entraves enfrentados pelo autor para viver única e exclusivamente da literatura, algo inviável naquele contexto dos anos 1900, não é difícil ler o romance A Amazônia misteriosa de Gastão Cruls na mesma chave interpretativa, embora os elementos biográficos e a trajetória de ambos se diferenciem. Como já ressaltado, a contraposição entre ciência e literatura pode ser identificada como eixo interpretativo da obra, na medida em que o próprio narrador se revela um médico que abandonou a carreira, da mesma forma como alguns contos anteriores já haviam revelado as angústias e desapontamentos do próprio Gastão Cruls quanto à carreira médica.

O imperceptível desvio de caminho tomado pelos três viandantes em meio a uma floresta sempre igual em suas trilhas é o momento de passagem 
e de transposição do limite a demarcar dois mundos e, por consequência, dois modos de representação da região: aquele do diário de viagem, impregnado pela necessidade de descrever realisticamente a paisagem, e um outro, desconhecido e maleável a uma fabulação de toda ordem, com o poder de baralhar a realidade com a dimensão onírica.

Quando acordei, alta noite, aos revérberos da fogueira, que fora atiçada pelo Piauí, trazia a lembrança de um sonho estranho. Como que por encanto, todos os vegetais da floresta haviam perdido a membrana de celulose, que os imobiliza, e eram agora entes sensificados que se moviam com desembaraço e vagueavam em liberdade, deslocando lentamente o raizame, à maneira dos grandes tentáculos (Cruls, s/d, p. 34).

A perda de referências para uma compreensão mais estável da realidade é aqui figurada por meio de um "sonho estranho" tido pelo narrador ao conceber as árvores da floresta em derredor como portadoras de vida autônoma, livres das amarras de suas raízes. A realidade ímpar da selva amazônica parece exigir de um narrador oriundo de um ambiente urbanizado um preço para que um sentido fosse viabilizado para aquela paisagem dominada pelo excesso de vegetação: livrar-se de suas amarras que eventualmente o prendem a uma dada realidade e, assim, soltar a imaginação. Mas a única possibilidade para tal preço ser efetivamente pago é o recurso às lendas e aos mitos amazônicos. O trabalho literário, a despeito das intenções realistas que poderiam se fazer presentes no projeto do autor, deverá trilhar esse caminho. Quando os três membros perdidos da comitiva são encontrados por um grupo de índios, todos se embrenham cada vez mais na floresta rumo à lendária cidade das mulheres guerreiras, as Amazonas.

Embora o desaparecimento e a morte do caboclo Piauí evidenciem os perigos que a selva apresenta na sua face mais cruel, ao se deparar com aquela cidade em plena selva, o narrador parece ainda não ter se desprendido completamente das referências de uma dada realidade, pois imagina ser um posto de caucheiros. Mas logo se vê obrigado a abandonar 
tal ideia em função da própria organização da cidade e das construções ali existentes. Um posto de caucheiros, como sabido, jamais possuiria tal ordem em função do caráter nômade do trabalho por eles desempenhado. O sertão amazônico, como relatado por Euclides da Cunha, era sempre um mundo de improviso e efêmero (Cunha, 1999).

Dir-se-ia a visão de um sonho, tal o espanto do que os meus olhos viam.

Em pleno coração da selva, na mais recôndita paragem, uma cidade em miniatura, com habitações bem construídas, ruas regulares, estradas largas, e até o arremedo de praças e jardins, onde muitas árvores deveriam ter sido plantadas pela mão do homem.

As casas, amplas, retangulares e dispostas a igual distância, obedeciam todas a um mesmo tipo: eram revestidas de um emboço de tabatinga e tinham por cobertura um telheiro vasto e acachapado, feito pelo ajustamento de grandes losangos de barro. Em muitas delas, esse telheiro, descansando sobre paredes baixas, alongava-se em beirais planos que, à guisa de alpendres, avarandavam uma faixa espaçosa de terreno, para onde se abriam portas e janelas. Daí o aspecto de rústicos bangalôs que tomavam todas aquelas casas, cercadas de copiares e ensombradas por tufos de palmeiras e espessas de taquara (Cruls, s/d, p. 64).

Um ambiente de urbanidade, portanto, bastante inusitado para aquelas paragens dominadas pela natureza. A cidade é um ambiente governado pelo homem conforme seu próprio ritmo, o avesso, portanto, do ritmo imposto pela natureza (Rama, 2015). A descrição pormenorizada feita pelo narrador da cidade ali vislumbrada projeta uma cidade idealizada, denunciando o que em seguida é revelado: trata-se da cidade mítica das guerreiras Amazonas, o País das pedras verdes. A revelação, por sua vez, é feita de maneira ainda mais inusitada, por meio de um alemão que ali se encontrava e que, ao fim e ao cabo, motivou a condução dos dois forasteiros perdidos na selva pelos índios que os encontraram. O aspecto físico e a indumentária usada pelo tal Dr. Hartmann são descritos pelo narrador 
de modo a lançar sobre ele certas suspeitas. Tais suspeitas são reforçadas pela observação do nordestino Pacatuba, sempre atento a sinais a indicar perigo: "Seu Doutor não reparou nos olhos de xexéu que ele tem? Aquilo não engana: é sinal de temperamento muito sanguinário" (Cruls, s/d, p. 71). Como no conto Flor do tabuleiro, os olhos azuis são interpretados pelo sertanejo nordestino como mau agouro.

O clima de mistério a cercar os propósitos do cientista alemão em plena selva amazônica vai se acentuando a cada momento do andamento da narrativa. Mas a presença da francesa Rosina, mulher do cientista, faz evidenciar os dramas do próprio autor quanto aos seus desapontamentos com a carreira médica e suas inclinações para uma carreira literária. O narrador, vale ressaltar, é um médico que desistiu da profissão, desencantado com os afazeres médicos. O contraste entre as personalidades de Rosina e do Dr. Hartmannn é traçado pelo narrador não só do ponto de vista físico (a rudeza de um e a delicadeza da outra), mas também como uma oposição entre a sensibilidade de uma e certa racionalidade "selvagem" do outro. Enquanto o alemão tenta convencer o narrador acerca da origem daquelas índias e daquela cidade como sendo o País das pedras verdes das lendárias Amazonas, reafirmando teses de exploradores do passado, Rosina encarrega-se de revelar o cotidiano da cidade e os costumes das índias que, dada a ausência de homens, criaram uma divisão de trabalho a definir uma partilha de atividades entre aquelas encarregadas de plantar, outras de produzir artesanato e as caçadoras e guerreiras. Enfim, uma ordem social definida por e para mulheres. O exercício de um "poder feminino" no plano mítico amazônico, dessa forma, revela-se como uma ideia a inverter e a contrastar com a submissão da mulher ao homem, do sentimento à razão.

A insatisfação crescente de Rosina em permanecer naqueles confins por mais tempo fez com que um conflito com o Dr. Hartmann se acentuasse com a chegada do médico/narrador e seu companheiro. A proximidade entre o narrador e a mulher do cientista alemão, por sua vez, fez crescer as afinidades entre ambos, desembocando em um caso amoroso. Foi Rosina 
quem lhe ofereceu um dos alucinógenos produzidos pelas índias. E foi por meio de um desses alucinógenos que o narrador entrou em transe e fez uma viagem ao passado distante, visitando as sociedades pré-colombianas desde os Astecas até os Incas. Conduzido pelo próprio Atahualpa, o então imperador dos incas quando da chegada dos espanhóis colonizadores, as alucinações do narrador fizeram com que ele constatasse o nível de organização daquelas civilizações e os avanços por elas alcançados do ponto de vista econômico, político e social. Não é difícil identificar nessa passagem do romance o objetivo de contrastar aquela realidade do passado com a situação precária do presente dos povos amazônicos. Com a colonização, assim insinua o narrador, houve uma degradação civilizacional, e não a instauração de um efetivo processo civilizador. O romance promove, nesse sentido, uma inversão de perspectiva ao identificar nos povos autóctones da América uma fonte mais genuína para fundamentar a própria sociedade nacional.

A descoberta dos experimentos científicos do Dr. Hartmann acentuou, por sua vez, essa inversão de perspectiva quanto ao valor a ser atribuído a uma civilização segundo os padrões e moldes da razão. A presença do narrador em plena selva amazônica já insinuava a sua descrença em relação à civilização europeia quando fez uma referência à guerra que então estava em curso na Europa. Segundo ele, a guerra poderia ser sintetizada como um conflito entre raças, opondo, por exemplo, alemães e franceses. A ânsia de dominação demonstrada pelos alemães no embate entre as nações reforçava, dessa forma, o caráter do Dr. Hartmann ao promover experiências para controlar a própria natureza, impondo uma ordem que pudesse ser dirigida pelo homem por via da racionalidade da ciência.

Para que melhor se pudessem estudar os produtos obtidos, entroncando-os na sua origem, o alemão mantinha, bem próximo de cada exemplar, os indivíduos que haviam sido acasalados. E assim surgiu a descendência bizarra da cutia com a preguiça, do macaco-prego com o tamanduaí, do peixe-boi com a anta. E isso sem falar no infindável cruzamento de aves de toda espécie, na mais louca e inimaginável das ornitologias... 
- É ou não é a verdadeira síntese das espécies? Inquiria a cada passo o Sr. Hartmann, possuído daquele mesmo entusiasmo de pouco antes, mas que já agora não me surpreendia tanto.

- Mas isso é o caos na natureza, dizia eu, boquiaberto.

- O caos, não! A ordem... porque esses cruzamentos nunca se poderão produzir espontaneamente. A ordem, porque assim nós temos a filogenia comprovada pela experiência (Cruls, s/d, p. 165-6).

Se o narrador demonstrava uma estranheza naquela união entre o médico alemão e a sua esposa francesa, uma união, segundo ele, entre duas raças em tudo opostas, vale destacar um outro casal de personagens a gravitar em torno do narrador e da francesa Rosina. Enquanto Pacatuba desempenhava o papel de interlocutor direto do narrador sempre a reforçar os contrastes entre a Amazônia e o sertão nordestino, Rosina estava sempre acompanhada de Malila, uma índia ainda adolescente a quem foi ensinada a língua francesa e de imediato destinada a acompanhar os visitantes. Se Pacatuba não conseguia admitir a ideia de uma índia falar francês (havia, para ele, algo de incongruente em tal fato), ao narrador e protagonista do romance parece não causar estranheza. A língua francesa, no entanto, é tomada como um ganho positivo da civilização europeia que merece ser preservado ou cultivado. Aliás, uma das experiências que o Dr. Hartmann pretendia levar adiante era justamente acerca da questão da afasia, ou seja, ele acreditava que, por meio de intervenções cirúrgicas no cérebro, seria possível proceder ao apagamento das diferentes línguas que alguém fosse capaz de falar, até atingir e preservar uma suposta língua ancestral. A relação entre linguagem e seu suporte orgânico era o pressuposto dos experimentos do cientista alemão. A dimensão propriamente cultural da linguagem como um aprendizado emerge no romance justamente da reação a tais intentos do Dr. Hartmann. 
A fuga daquele local por parte de Pacatuba e do narrador, acompanhados de Rosina e com o apoio de Malila, foi precipitada justamente pela desconfiança da realização de tais experimentos de afasia no próprio médico/ narrador ou em Rosina ou em Malila. O desfecho da trama, no entanto, mostrou-se trágico para a francesa. Com a perseguição dos índios que habitavam os arredores da cidade das Amazonas, uma flecha foi disparada contra ela. Após cair ferida na água, foi atacada por piranhas, morrendo em seguida. O sertanejo Pacatuba, que já havia alertado o médico sobre os maus presságios para uma fuga naquele dia em função do canto de uma acauã, tentou consolar seu companheiro aconselhando-o a beijar a morta, sem mais necessidade de esconder ou dissimular o sentimento que havia vicejado entre ambos. Para o amor não há disfarces ou dissimulações possíveis. "[...] Paixão de amor não se esconde... É como o mel-de-pau lá do nosso agreste, mesmo metido em oco das árvores, ele está cheirando longe" (Cruls, s/d, 222).

\section{Conclusão}

Embora o desfecho do romance seja trágico e abrupto, o silêncio que se segue ao beijo em Rosina já desfalecida prenuncia uma necessidade do autor de prolongar a sua abordagem acerca da Amazônia. O engajamento de Gastão Cruls para fazer parte da comitiva chefiada por Rondon e destinada a tratar dos limites entre o Brasil e a Guiana Holandesa insinuava um novo projeto para um romance amazônico, mas desembocou em um diário de viagem, A Amazônia que eu vi. Um livro que foi tomado equivocadamente pela crítica como uma espécie de complemento do romance. Se o romance era, a princípio, fruto da imaginação, o relato de viagem seria a constatação in loco de uma realidade a ser vivenciada pelo autor. Mas, como aqui analisado, a imaginação do romance não se apartou do sentido de realidade presente nos relatos de viagem e nas lendas e mitos amazônicos. Como salientou de maneira um tanto quanto jocosa o crítico amazonense Péricles Moraes em seu artigo Os intérpretes da Amazônia, Gastão Cruls viu melhor 
a Amazônia quando priorizou o uso da imaginação (Moraes, 1935, p. 23). Mas o autor de Amazônia misteriosa já estava, desde então, consciente das implicações presentes nos processos de representação literária da realidade.

Marco Aurélio Coelho Paiva é Doutor em Sociologia e Professor Associado III do Departamento de Ciências Sociais da Universidade Federal do Amazonas.

$\equiv$ marco_paiva36@hotmail.com

\section{Referências}

1. BARRETO, Lima. À margem do Coivara, de Gastão Cruls. In: Impressões de leitura e outros textos críticos. São Paulo: Penguin Classics/Companhia das Letras, 2017, p. 247-52.

2. CANDIDO, Antonio. O discurso e a cidade. $2^{\underline{a}}$ ed. São Paulo: Livraria Duas Cidades, 1998.

3. CONAN DOYLE, Arthur. O mundo perdido. Trad. Luiz Horácio da Matta. Rio de Janeiro: Livraria Francisco Alves, 1982.

4. CRULS, Gastão. A Amazônia misteriosa. 2. ed. São Paulo: Ed. Saraiva, s/d.

5. CRULS, Gastão. Coivara. 2. ed. Rio de Janeiro: Livraria Castilho, 1922.

6. CRULS, Gastão. Ao embalo da rede. Rio de Janeiro: Livraria Castilho, 1923.

7. CRULS, Gastão. A criação e o criador. São Paulo: Companhia Editora Nacional, 1928.

8. CRULS, Gastão. Vertigem. Rio de Janeiro: Ariel, 1934.

9. CRULS, Gastão. Elza e Helena. 3. ed. São Paulo: Companhia Editora Nacional, 1949.

10. CRULS, Gastão. Antônio Torres e seus amigos. São Paulo: Companhia Editora Nacional, 1950.

11. CRULS, Gastão. De pai a filho. Rio de Janeiro: Livraria José Olympio Ed., 1954.

12. CRULS, Gastão. A Amazônia que eu vi. 5. ed. Rio de Janeiro/Brasília: Livraria José Olympio/Instituto Nacional do Livro, 1973.

13. CRULS, Gastão. Hileia amazônica: aspectos da flora, fauna, arqueologia e etnografia indígenas. Belo Horizonte: Ed. Itatiaia, 2003.

14. CUNHA, Euclides da. À margem da história. São Paulo: Martins Fontes, 1999. 
15. GINZBURG, Carlo. Sinais: raízes de um paradigma indiciário. In: Mitos, emblemas, sinais: morfologia e história. 2. ed. Trad. Federico Carotti. São Paulo: Companhia das Letras, 2007, p. 143-79.

16. GONDIM, Neide. A invenção da Amazônia. São Paulo: Marco Zero, 1994.

17. HABERMAS, Jürgen. Mudança estrutural da esfera pública: investigações quanto a uma categoria da sociedade burguesa. 2. ed. Trad. Flávio Kothe. Rio de Janeiro: Tempo Brasileiro, 2003.

18. LIMA, Luiz C. O controle do imaginário \& a afirmação do romance: Dom Quixote, As relações perigosas, Moll Flanders, Tristram Şhandy. São Paulo: Companhia das Letras, 2009.

19. LOBATO, Monteiro. O presidente negro. 2. ed. São Paulo: Ed. Globo, 2009. 20. MENEZES, Raimundo. Dicionário literário brasileiro. 2. ed. Rio de Janeiro: Livros Técnicos e Científicos, 1978.

21. MICELI, Sérgio. Intelectuais à brasileira. São Paulo: Companhia das Letras, 2001.

22. MICELI, Sérgio. Vanguardas em retrocesso: ensaios de história social e intelectual do modernismo latino-americano. São Paulo: Companhia das Letras, 2012.

23. MORAES, Péricles. Legendas e águas-fortes. Manaus: Livraria Clássica, 1935. 24. MURARI, Luciana. Natureza e cultura no Brasil (1870-1922). São Paulo: Alameda, 2009.

25. ORTIZ, Renato. Cultura brasileira \& identidade nacional. 5. ed. São Paulo: Brasiliense, 1994.

26. PAES, José P. O art nouveau na literatura brasileira. In: Gregos \& baianos: ensaios. São Paulo: Ed. Brasiliense, 1985, p. 64-80.

27. PRADO, Antônio A. Itinerário de uma falsa vanguarda: os dissidentes, a Semana de 22 e o Integralismo. São Paulo: Ed. 34, 2010.

28. RAMA, Ángel. A cidade das letras. Trad. Emir Sader. São Paulo: Boitempo, 2015.

29. RANGEL, Alberto. Inferno verde: cenas e cenários do Amazonas. 5. ed. Manaus: Ed. Valer/Governo do Estado do Amazonas, 2001.

30. SILVA, Alexandre M. da. O admirável mundo novo da República Velha: $\mathrm{O}$ nascimento da ficção científica brasileira no começo do século XX. 2008. 193 p. Tese (Doutorado em Ciência da Literatura) - UFRJ, Rio de Janeiro, 2008.

31. SIMMEL, Georg. As grandes cidades e a vida do espírito. Trad. Leopoldo Waizbort. In: BOTELHO, André (org.). Sociologia essencial. São Paulo: Peguin Classics/Companhia das Letras, 2013, p. 311-29.

32. SCHWARCZ, Lilia M. O espetáculo das raças: cientistas, instituições e questão racial no Brasil (1870-1930). São Paulo: Companhia das Letras, 2011. 
33. TODOROV, Tzvetan. Introdução à literatura fantástica. Trad. Maria Clara Correa Castello. 4. ed. São Paulo: Perspectiva, 2010.

34. VÍVOLO, Vítor da M. Gastão Cruls e a auscultação da sociedade brasileira. 2017. 126 p. Dissertação (Mestrado em História) - PUC/SP, São Paulo.

35. WELLS, H. G. A ilha do Dr. Moreau. Trad. Bráulio Tavares. Rio de Janeiro: Objetiva, 2012.

Recebido: 7 ago. 2018

Aceito: 18 dez. 2018 